\title{
Analisis Video Comments To Followers Ratio Instagram Pada 6 Daftar Merk Laptop Terbaik Paling Banyak Digunakan
}

\author{
I Made Pratama Dwi Saputra \\ pratamadwisaputra.46@gmail.com
}

\begin{abstract}
Information and Communication Technology that has developed from time to time is able to make everyone more active in using social media. Social media has become inseparable in everyday life, especially among teenagers, where they can share information or do other things for fun. One of the social media that currently has a big influence is Instagram. Instagram is a photo and video sharing application that allows users to take photos, take videos, apply digital filters, and share them on various social networking services, including Instagram's own. The author conducted this study aimed at finding the ratios found on Instagram social media which later these ratios were used to perform mathematically measured analyzes. This study uses quantitative exploratory research methods to find variables contained in social media Instagram. From research conducted on Instagram social media, it shows that there are 14 ratios that can be used to assess, measure, and also compare the credibility of an Instagram account. This study focuses on calculating the credibility of the Video Comments To Followers Ratio on the 6 Most Used Best Laptop Brands List.
\end{abstract}

\begin{abstract}
ABSTRAK
Teknologi Informasi dan Komunikas yang telah berkembang dari waktu ke waktu hingga mampu membuat setiap orang menjadi lebih aktif dalam menggunakan media sosial. Sosial media menjadi tidak terpisahkan dalam kehidupan sehari - hari terutama di kalangan remaja, yang di mana mereka dapat berbagi informasi atau melakukan hal - hal lain untuk bersenang - senang. Sosial media yang saat ini memiliki pengaruh besar salah satunya yaitu Instagram. Instagram adalah sebuah aplikasi berbagi foto dan video yang memungkinkan pengguna mengambil foto, mengambil video, menerapkan filter digital, dan membagikannya ke berbagai layanan jejaring sosial, termasuk milik Instagram sendiri. Penulis melakukan penelitian ini bertujuan untuk menemukan rasio - rasio yang terdapat pada sosial media Instagram yang nantinya rasio - rasio tersebut digunakan untuk melakukan analisa yang terukur secara matematis. Penelitian ini menggunakan metode penelitian eksploratif kuantitatif untuk menemukan variable yang terdapat di sosial media Instagram. Dari penelitian yang dilakukan terhadap sosial media Instagram ini menunjukkan bahwa terdapat 14 rasio yang bisa digunakan untuk menilai, mengukur, dan juga membandingkan kredibilitas dari sebuah akun Instagram. Penelitian ini berfokus untuk menghitung kredibilitas dari Video Comments To Followers Ratio pada 6 Daftar Merk Laptop Terbaik Paling Banyak Digunakan.
\end{abstract}

Kata Kunci : Media sosial; Instagram; Rasio Instagram; Kredibilitas Akun Sosial Media. 


\section{PENDAHULUAN}

Pada era globalisasi seperti sekarang ini kebutuhan untuk berinteraksi menjadi semakin meningkat, penemuan teknologi informasi (internet) yang berkembang secara massal, kemudian teknologi itu mengubah bentuk masyarakat, dari masyarakat dunia lokal menjadi masyarakat dunia global (Nainggolan et al., 2018). Kemajuan teknologi telah mengantarkan manusia untuk menciptakan bentuk baru dalam berinteraksi dan bersosialisasi, salah satunya adalah inovasi teknologi komunikasi berupa media sosial. Sebagai sarana komunikasi yang efektif, media sosial sangat berperan dalam aktifitas keseharian bersosial di masyarakat (Mahendra, 2017).

Media Sosial merupakan media online yang digunakan untuk kebutuhan komunikasi, berinteraksi, berpartisipasi, berbagi dan menciptakan isi/konten untuk digunakan para penggunanya melalui perangkat aplikasi khusus dengan jaringan internet tanpa dibatasi oleh ruang atau waktu, yang saat ini erat dengan kehidupan remaja. Dengan pesatnya perkembangan new media, telah memberikan dampak terhadap situs-situs komunikasi, dari yang awalnya hanya berupa email dan chatting hingga menjadi media sosial atau jejaring sosial seperti Facebook, Twitter, Instagram, Path, Snapchat. Salah satu media sosial yang sedang banyak digunakan oleh pengguna gadget saat ini adalah Instagram (Nainggolan et al., 2018).

Instagram memiliki lebih dari 1 miliyar pengguna aktif. Instagram adalah media sosial yang digunakan sebagai tempat menyebarkan dan berbagai informasi, berinteraksi dengan orang banyak, serta dapat mengenal lebih dekat dengan sesama pengguna. Instagram merupakan aplikasi berbagi foto yang memungkinkan pengguna mengambil foto, menerapkan filter digital, dan membagikannya ke berbagai layanan jejaring sosial. Maraknya penggunaan Instagram membuat para peneliti ingin melakukan penilaian secara kualitatif terhadap akun-akun yang ada pada media sosial Instagram (Hendika Permana, 2021).

Maraknya penggunaan Instagram membuat para peneliti ingin melakukan penilaian secara kualitatif terhadap akun-akun yang ada pada media sosial Instagram. Beberapa para peneliti telah melakukan penelitian yang terkait dengan penggunaan media sosial Instagram. Namun diantara beberapa penelitian yang sudah ada mengenai Instagram, belum ada peneliti yang meneliti tentang pencarian rasio-rasio yang dapat digunakan sebagai alat ukur dalam menilai berbagai aspek pada Instagram. Rasio-rasio ini yang nantinya dapat digunakan untuk melakukan analisa atau penelitian kuantitatif. Beberapa aspek yang dapat dinilai menggunakan rasio-rasio hasil dari penelitian tersebut yaitu, yang pertama ingetsmen yang ada pada akun Instagram tersebut, apakah ingetsmen dari akun tersebut sudah bagus atau belum. Kedua, rasio-rasio ini juga bisa digunakan untuk mengukur kredibilitas dari akun Instagram tersebut. Dan yang ketiga, untuk menilai performa dari konten atau post yang posting pada akun Instagram tersebut (Hendika Permana, 2021). 
Terdapat cukup banyak akun-akun media sosial terutama Instagram yang dimiliki oleh perusahaan laptop ternama, contohnya seperti perusahaan laptop yang saat ini nama dari produknya telah berkembang dan banyak digunakan oleh semua orang. Adapun 6 Daftar Merk Laptop Terbaik Paling Banyak Digunakan, merk-merk tersebut diantaranya yaitu : Asus Indonesia, Apple, Dell, Acer Indonesia, Hp Indonesia, Lenovo Indonesia (Sukma Convert, 2021).

Dalam penelitian ini penulis menggunakan metode eksploratif kuantitatif dengan menggunakan rasio-rasio yang ada pada Instagram sebagai tolak ukur perhitungannya. Pada penelitian ini penulis hanya berfokus untuk menghitung kredibilitas Video Comments To Followers Ratio Instagram pada 6 Daftar Merk Laptop Terbaik Paling Banyak Digunakan. Penelitian ini bertujuan untuk mengetahui kredibilitas performa akun Instagram dari 6 Daftar Merk Laptop Terbaik Paling Banyak Digunakan dengan menggunakan Video Comments To Followers Ratio (Sukma Convert, 2021).

\section{TINJAUAN PUSTAKA}

Kemajuan teknologi telah mengantarkan manusia untuk menciptakan bentuk baru dalam berinteraksi dan bersosialisasi, salah satunya adalah inovasi teknologi komunikasi berupa media sosial. Sebagai sarana komunikasi yang efektif, media sosial sangat berperan dalam aktifitas keseharian bersosial di masyarakat. Lahirnya media sosial menjadikan pola perilaku masyarakat mengalami pergeseran baik budaya, etikan dan norma yang ada. Teknologi komunikasi sangat penting dalam masyarakat informasi, karena dengan teknologi ini memudahkan orang untuk bertukar informasi dengan orang lain melalui sistem komunikasi. Keberadaan sarana komunikasi memberikan dampak yang signifikan di berbagai bidang seperti sosial, ekonomi, pendidikan, dan bidang-bidang lainnya. Komunikasi tidak hanya dilakukan secara fisik, tetapi dapat dilakukan dengan berbagai media sosial seperti dunia maya (Mahendra, 2017).

Instagram atau sering disebut IG merupakan jenis media sosial berupa aplikasi yang digunakan penggunanya untuk berbagi gambar serta video dan dapat menerapkan filter pada foto maupun video kemudian menyebarkannya ke jejaring sosial lainnya. Instagram berasal dari dua kata, yaitu "insta" dan "gram". Kata "insta" berasal dari kata instan, yang berarti pengguna aplikasi ini dapat membagikan foto maupun video secara instan. Sedangkan "gram" berasal dari kata telegram, yang berarti penguna aplikasi ini dapat membagikan foto maupun video dengan cepat (Feroza \& Misnawati, 2020).

Seiring berjalannya waktu instagram mulai berkembang yang awalnya sebatas media untuk saling berkomunikasi kini menjadi salah satu media yang menyediakan berbagai informasi baik itu ilmu pengatuhan umum hingga sampai kepada kejadian yang sedang viral. Selain itu, instagram juga menjadi media yang digunakan untuk berbagai kepentingan salah satunya sebagai wadah transaksi online yang menawarkan barang dan jasa yang kemudian dikenal dengan konsep online shop. Berkat instagram yang semakin inovatif dalam hal fitur menyebabkan jumlah penggunanya terus bertambah hingga merambah ke ranah pendidikan yaitu para civitas akademik dalam hal ini mahasiswa. Mahasiwa yang memiliki fungsi sebagai salah satu agen perubahan menggunakan 
instagram sebagai wadah untuk berkarya dan berinovasi. Selain itu, mahasiswa juga memanfaatkan instagram untuk menawarkan barang ataupun jasa kepada pengguna instagram lainnya, dimana hal itu mereka jadikan sebagai mata pencaharian (Maulhayat et al., 2018).

\section{METODE PENELITIAN}

Penelitian ini menggunakan metode eksploratif kuantitatif yang memiliki tujuan untuk mengetahui kredibilitas dari performa akun Instagram dari 6 Daftar Merk Laptop Terbaik Paling Banyak Digunakan. Metode eksploratif merupakan penelitian yang bertujuan untuk memperdalam pengetahuan dan mencari ide-ide baru mengenai suatu gejala tertentu, menggambarkan fenomena sosial, dan menjelaskan bagaimana terjadinya suatu fenomena sosial untuk merumuskan masalah secara lebih terperinci atau mengembangkan hipotesis bukan menguji hipotesis (Mudjiyanto, 2018).

Tujuan dari penelitian ini yaitu untuk mengetahui nilai kredibillitas dari performa akun Instagram 6 Daftar Merk Laptop Terbaik Paling Banyak Digunakan. Terdapat beberapa langkah yang harus dilakukan dalam penelitian ini, sehingga mampu menemukan peringkat pertama dari akun Instagram Merk Laptop Terbaik Paling Banyak Digunakan yang memiliki performa terbaik. Langkah-langkah yang dilakukan pada penelitian ini, diantaranya yaitu :

\section{Melakukan Eksplorasi pada Website untuk Menentukan Objek yang Akan Dianalisa.}

Eksplorasi ini dilakukan pada beberapa halaman website yang menyediakan informasi mengenai objek yang akan di teliti. Setelah eksplorasi selesai dilakukan, sehingga akan ditemukan nama-nama dari Merk Laptop Terbaik Paling Banyak Digunakan yang akan dijadikan objek analisa. Setelah melakukan eksplorasi pada halaman website, maka langkah selanjutnya adalah mencari nama akun Instagram dari masing-masing merk laptop terbaik yang akan dijadikan sebagai objek penelitian. Serta harus dipastikan semua daftar merk laptop tersebut harus memiliki akun pada aplikasi sosial media yaitu Instagram.

\section{Menghitung Nilai Rata-Rata Variable Dari 6 Daftar Merk Laptop Terbaik Paling Banyak Digunakan.}

Pada langkah ini, peneliti menghitung nilai variable video comments dan variable followers. Variabel merupakan suatu objek, atau sifat, atau atribut atau nilai dari orang, atau juga kegiatan yang mempunyai bermacam-macam variasi antara satu dengan lainnya yang ditetapkan oleh peneliti dengan tujuan untuk dipelajari dan ditarik kesimpulan. Berdasarkan hal tersebut, dapat diartikan bahwa variabel merupakan segala sesuatu yang akan menjadi objek pengamatan penelitian, dimana didalamnya terdapat faktor-faktor yang berperan dalam peristiwa atau hal-hal yang akan diteliti. Variabel dapat diartikan sebagai sifat yang akan diukur atau diamati yang nilainnya bervariasi antara satu objek ke objek lainnya (Purwanto, 2019). Untuk menghitung nilai rata-rata dari variabel video comments dan variabel video views yaitu dengan cara mengambil minimal 10 postingan kemudian di hitung sehingga menemukan nilai ratarata dari masing-masing variabel. 


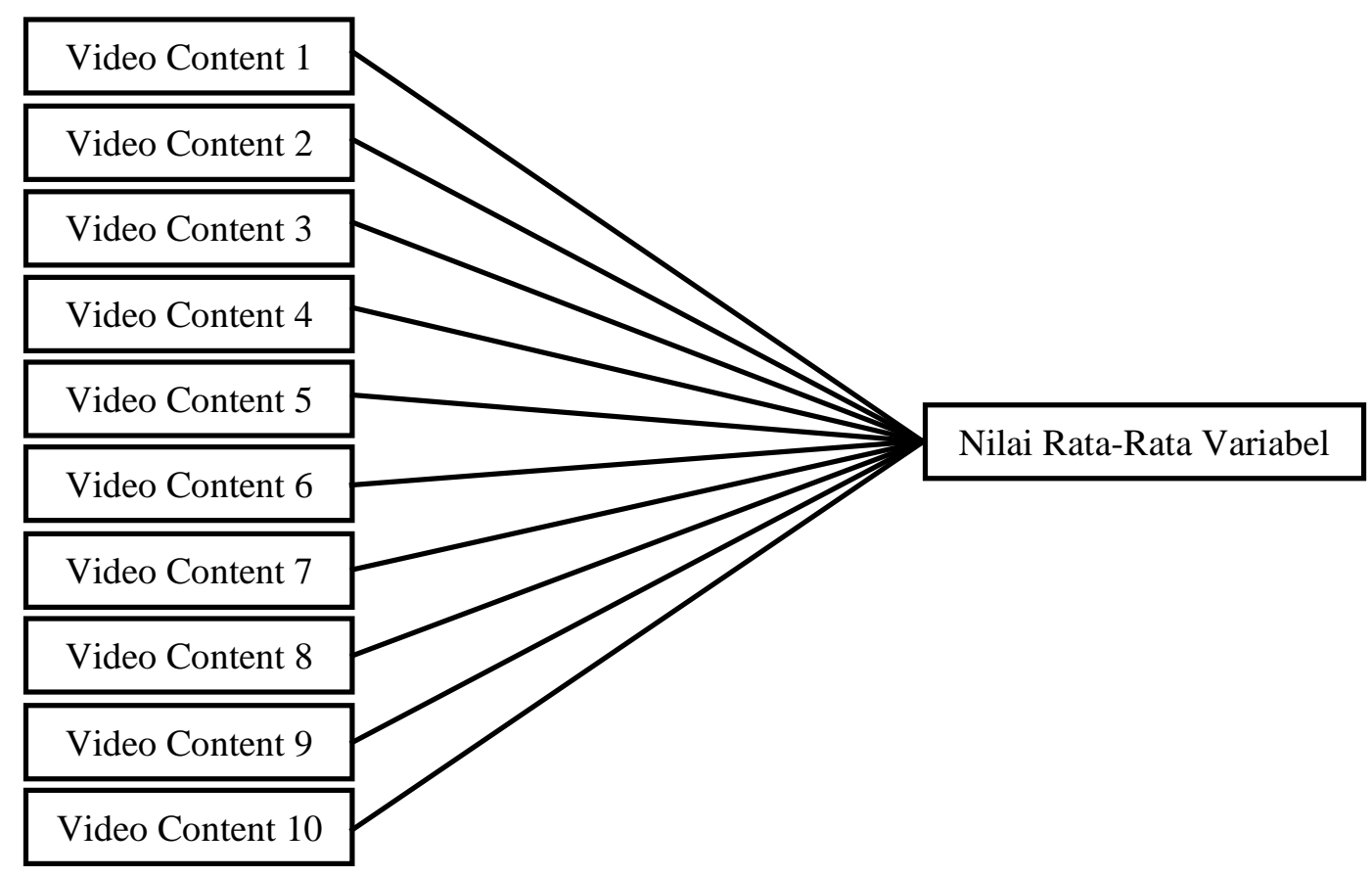

Gambar 1. Analisa Nilai Rata-Rata Variabel

\section{Menghitung Nilai Kredibilitas Rasio}

Untuk menghitung nilai kredibilitas dari Video Comments To Followers Ratio, peneliti menggunakan suatu cara yaitu membagi nilai variabel pertama dengan nilai variabel kedua. Jika video comments memiliki nilai 100 dan followers memiliki nilai 300, maka cara menghitungnya yaitu $100: 300=0,3$. Dengan begitu nilai dari Video Comments To Followers Ratio adalah 0,3.

\section{Menentukan Peringkat Pada Akun Instagram}

Pada langkah terakhir yang dilakukan pada penelitian ini yaitu menentukan peringkat pada masing-masing rasio yang ada yakni dari 6 Daftar Merk Laptop Terbaik Paling Banyak Digunakan. Pada penentuan peringkat perlu melihat karakteristik dari rasio yang di teliti. Jika karakteristik rasio yang di dapat adalah rendah, maka objek yang memiliki nilai terendah akan mendapatkan angka 6 dan objek yang memiliki nilai tertinggi akan mendapatkan angka 1. Namun jika rasio yang di dapat memiliki karakteritik tinggi maka objek yang mendapatkan nilai tinggi akan mendapatkan angka 6 dan objek yang mendapatkan nilai terendah akan mendapatkan angka 1. Setelah mendapatkan hasil kredibilitas ratio maka dapat disimpulkan objek yang mana mendapatkan peringkat 1 sampai dengan peringkat 6 .

Pada penelitian yang dilakukan oleh penulis ini memperoleh rasio yang memiliki karakteristik tinggi. Maka objek yang mendapatkan nilai tinggi akan mendapatkan angka 6 dan objek yang mendapatkan nilai terendah akan mendapatkan angka 1. Jadi, yang memperoleh angka 6 dari 6 Daftar Merk Laptop Terbaik Paling Banyak Digunakan adalah lenovoid dan yang memperoleh angka 1 adalah asusid. 


\section{HASIL DAN PEMBAHASAN}

Akun Instagram dari 6 Daftar Merk Laptop Terbaik Paling Banyak Digunakan, diantaranya yaitu :

1. asusid

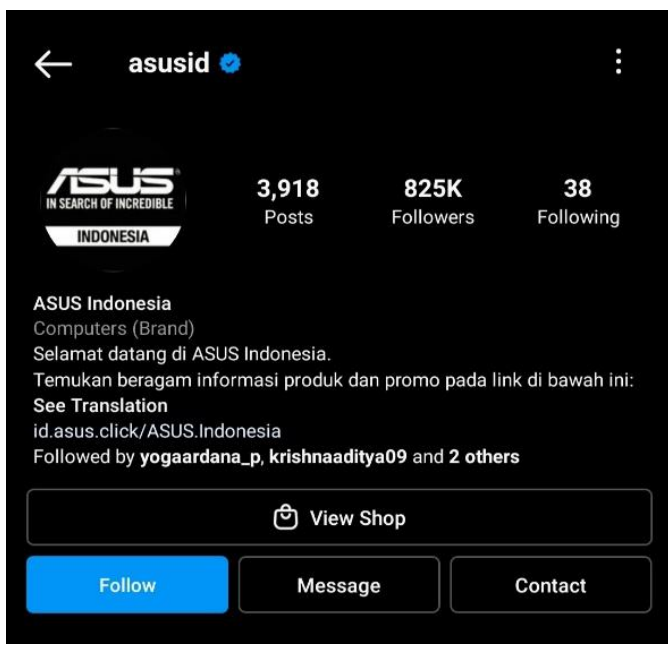

Gambar 1. Akun Instagram Asus Indonesia https://instagram.com/asusid?utm_medium=copy_link (Akses pada 21 Oktober 2021)

\section{2. apple}

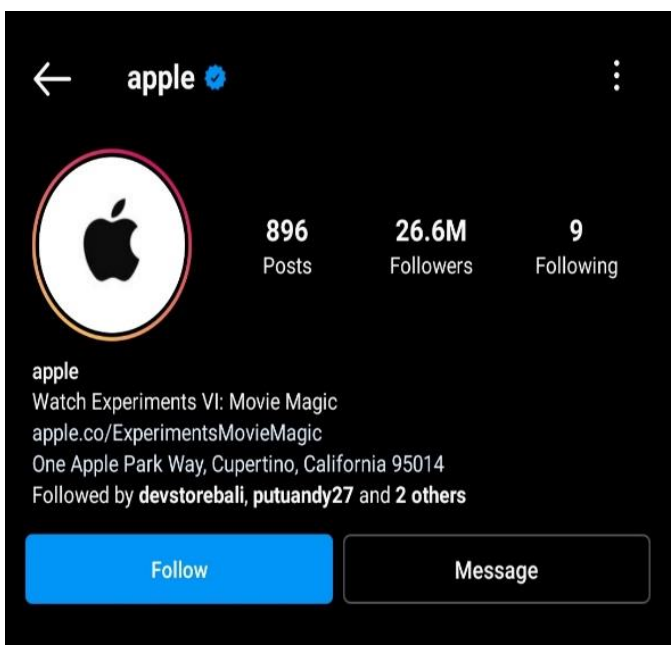

Gambar 2. Akun Instagram Apple

https://instagram.com/apple?utm_medium=copy_link (Akses pada 21 Oktober 2021) 
3. dell

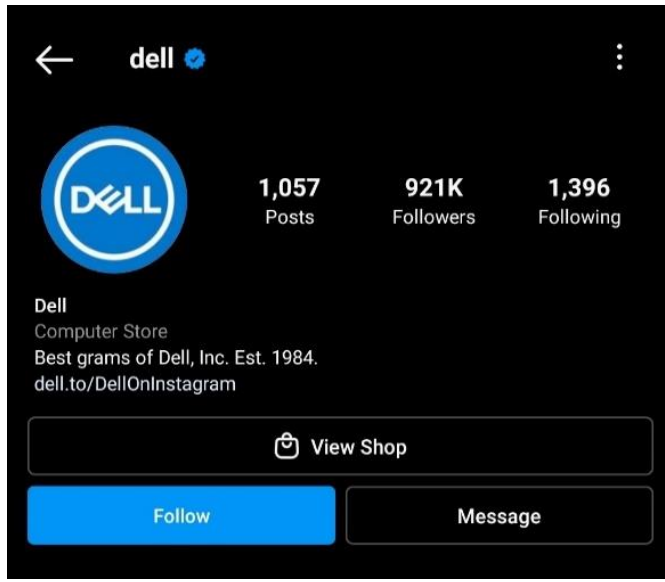

Gambar 3. Akun Instagram Dell

https://instagram.com/dell?utm_medium=copy_link (Akses pada 21 Oktober 2021)

\section{4. acerid}

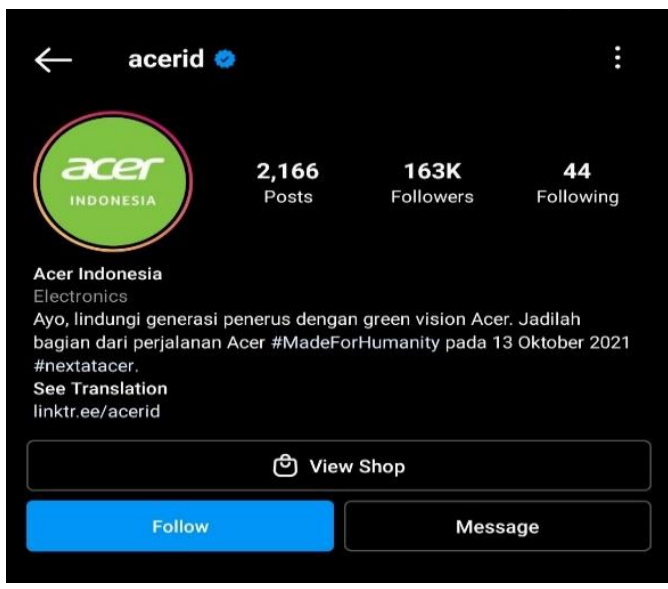

Gambar 4. Akun Instagram Acer Indonesia https://instagram.com/acerid?utm_medium=copy_link (Akses pada 21 Oktober 2021)

\section{5. hpindonesia}

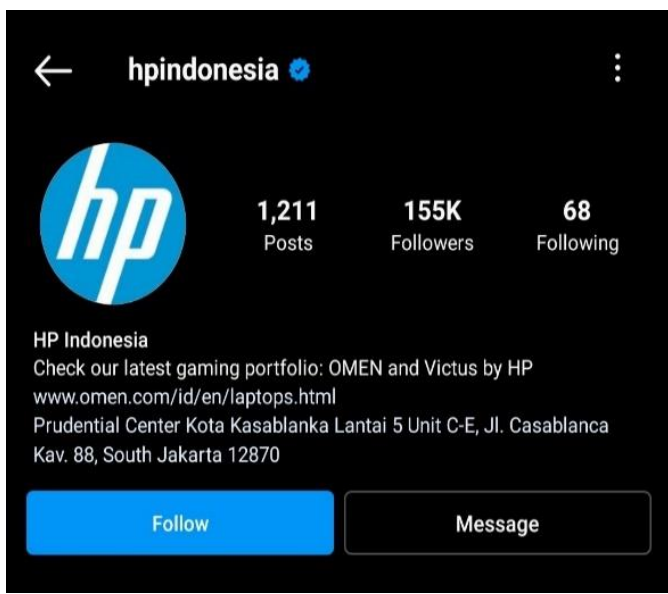

Gambar 5. Akun Instagram HP Indonesia

https://instagram.com/hpindonesia?utm_medium=copy_link (Akses pada 21 Oktober 2021) 


\section{6. lenovoid}

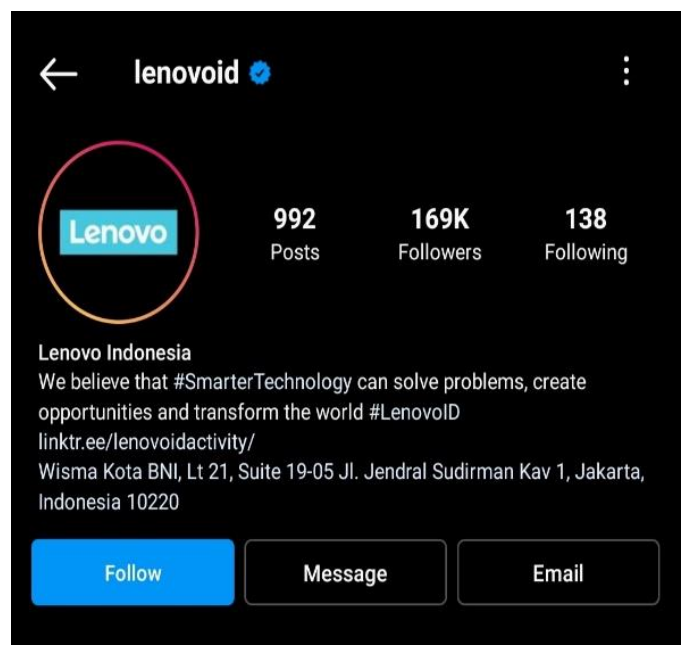

Gambar 6. Akun Instagram Lenovo Indonesia https://instagram.com/lenovoid?utm_medium=copy_link

(Akses pada 21 Oktober 2021)

Dari keenam akun Instagram 6 Daftar Merk Laptop Terbaik Paling Banyak Digunakan, peneliti mendapatkan atau menemukan nilai dari masing-masing variabel yang ada pada pada akun Instagram. Dimana, variabel tersebut akan digunakan untuk menghitung rasio Video Comments to Followers dari setiap akun Instagram. Terdapat 8 variabel yang ada pada akun Instagram, diantaranya yaitu :

1. Posts

2. Followers

3. Following

4. Image Likes

5. Image Comments

6. Video Views

7. Video Likes

8. Video Comments

Dari 8 variabel yang terdapat pada akun Instagram yang telah disebutkan di atas, peneliti hanya fokus untuk menemukan hasil dari 2 variabel sesuai dengan judul yang dipilih oleh penulis, 2 variabel tersebut yaitu :

1. Video Comments

2. Followers

Kedua variabel di atas kemudian dilakukan analisa oleh penulis untuk dapat mencari atau menemukan nilai rata-rata dari variabel video comments dan variabel followers. Untuk menghitung nilai rata-rata dari variabel video comments dan variabel followers, penulis mengambil sampel sebanyak 10 postingan video dari setiap akun Instagram diatas dan kemudian di hitung sehingga menemukan nilai rata-rata dari masing-masing varabel. Berikut ini merupakan table nilai rata-rata dari setiap masing-masing merk laptop terbaik yang paling banyak digunakan, yaitu : 
Tabel 1. Analisa Nilai Rata-Rata dari Variabel Video Comments dan Followers pada Akun Instagram "asusid"

\begin{tabular}{|r|r|r|}
\hline \multicolumn{3}{|c|}{ Asusid } \\
\hline No & Video Comments & Followers \\
\hline 1 & 60 & 824.805 \\
\hline 2 & 45 & \\
\hline 3 & 97 & \\
\hline 4 & 46 & \\
\hline 5 & 67 & \\
\hline 6 & 26 & \\
\hline 7 & 24 & \\
\hline 8 & 89 & \\
\hline 9 & 36 & \\
\hline 10 & 37 & \\
\hline Total & 53 & $\mathbf{8 2 4 . 8 0 5}$ \\
\hline Sumber : Pengolah Data Microsoft Excel
\end{tabular}

Sumber : Pengolah Data Microsoft Excel

Tabel 2. Analisa Nilai Rata-Rata dari Variabel Video Comments dan Followers pada Akun Instagram "apple"

\begin{tabular}{|r|r|r|}
\hline \multicolumn{3}{|c|}{ apple } \\
\hline No & Video Comments & Followers \\
\hline 1 & 576 & 26.610 .293 \\
\hline 2 & 381 & \\
\hline 3 & 662 & \\
\hline 4 & 685 & \\
\hline 5 & 568 & \\
\hline 6 & 631 & \\
\hline 7 & 443 & \\
\hline 8 & 714 & \\
\hline 9 & 6.247 & \\
\hline 10 & 8.262 & \\
\hline Total & 1.917 & 26.610 .293 \\
\hline
\end{tabular}

Sumber : Pengolah Data Microsoft Excel 
Tabel 3. Analisa Nilai Rata-Rata dari Variabel Video Comments dan Followers pada Akun Instagram "dell"

\begin{tabular}{|r|r|r|}
\hline \multicolumn{3}{|c|}{ dell } \\
\hline No & Video Comments & Followers \\
\hline 1 & 18 & 919.610 \\
\hline 2 & 31 & \\
\hline 3 & 44 & \\
\hline 4 & 113 & \\
\hline 5 & 151 & \\
\hline 6 & 41 & \\
\hline 7 & 81 & \\
\hline 8 & 115 & \\
\hline 9 & 51 & \\
\hline 10 & 236 & \\
\hline Total & $\mathbf{8 8}$ & $\mathbf{9 1 9 . 6 1 0}$ \\
\hline Sumber $:$ Pengolah Data Microsoft Excel
\end{tabular}

Sumber : Pengolah Data Microsoft Excel

Tabel 4. Analisa Nilai Rata-Rata dari Variabel Video Comments dan Followers pada Akun Instagram "acerid"

\begin{tabular}{|r|r|r|}
\hline \multicolumn{3}{|c|}{ acerid } \\
\hline No & Video Comments & Followers \\
\hline 1 & 19 & 163.479 \\
\hline 2 & 19 & \\
\hline 3 & 19 & \\
\hline 4 & 23 & \\
\hline 5 & 8 & \\
\hline 6 & 11 & \\
\hline 7 & 25 & \\
\hline 8 & 15 & \\
\hline 9 & 49 & \\
\hline 10 & 88 & \\
\hline Total & 28 & 163.479 \\
\hline
\end{tabular}

Sumber : Pengolah Data Microsoft Excel 
Tabel 5. Analisa Nilai Rata-Rata dari Variabel Video Comments dan Followers pada Akun Instagram "hpindonesia"

\begin{tabular}{|r|r|r|}
\hline \multicolumn{3}{|c|}{ hpindonesia } \\
\hline No & Video Comments & Followers \\
\hline 1 & 13 & 154.088 \\
\hline 2 & 20 & \\
\hline 3 & 59 & \\
\hline 4 & 41 & \\
\hline 5 & 83 & \\
\hline 6 & 59 & \\
\hline 7 & 84 & \\
\hline 8 & 29 & \\
\hline 9 & 70 & \\
\hline 10 & 83 & \\
\hline Total & 54 & \\
\hline Sumb & 154.088 \\
\hline
\end{tabular}

Sumber : Pengolah Data Microsoft Excel

Table 6. Analisa Nilai Rata-Rata dari Variabel Video Comments dan Followers pada Akun Instagram "lenovoid"

\begin{tabular}{|r|r|r|}
\hline \multicolumn{3}{|c|}{ lenovoid } \\
\hline No & Video Comments & Followers \\
\hline 1 & 121 & 169.241 \\
\hline 2 & 71 & \\
\hline 3 & 34 & \\
\hline 4 & 61 & \\
\hline 5 & 32 & \\
\hline 6 & 10 & \\
\hline 7 & 88 & \\
\hline 8 & 343 & \\
\hline 9 & 145 & \\
\hline 10 & 242 & \\
\hline Total & 115 & \\
\hline
\end{tabular}

Sumber : Pengolah Data Microsoft Excel

Setelah menghitung nilai rata-rata tersebut, maka akan menemukan hasil akhir dari nilai rata-rata yang dicari pada variabel video comments dan variabel followers. Hasil akhir dari nilai rata-rata variabel video comments dan variabel followers yaitu : 
Tabel 7. Nilai Variabel Pada Akun Instagram 6 Daftar Merk Laptop Terbaik Paling Banyak Digunakan

Tabel Nilai Masing-Masing Variable

\begin{tabular}{|c|r|r|r|r|r|r|}
\hline Variable & \multicolumn{1}{c|}{ asusid } & \multicolumn{1}{c|}{ apple } & \multicolumn{1}{c|}{ dell } & acerid & hpindonesia & lenovoid \\
\hline Video Comments & 53 & 1.917 & 88 & 28 & 54 & 115 \\
\hline Followers & 824805 & 26610293 & 919610 & 163479 & 154088 & 169241 \\
\hline
\end{tabular}

Sumber : Pengolah Data Microsoft Excel

Pada akun Instagram terdapat 14 rasio yang relevan digunakan untuk mengukur kredibilitas pada masing-masing akun. Namun, pada penelitian kali ini penulis hanya menitik fokuskan penelitian ini untuk menghitung Video Comments to Followers Ratio. Untuk menghitung kredibilitas dari masing-masing akun Instagram dari setiap merk laptop yang paling banyak digunakan, peneliti melakukan perhitungan atau menghitung dengan menggunakan cara : variabel 1 akan dibagi dengan variabel 2, sehingga akan ditemukan hasil analisis dari rasio tersebut.

Tabel 8. Hasil Perhitungan dari Rasio Akun Instagram

\begin{tabular}{|c|c|c|c|c|c|c|c|}
\hline \multicolumn{7}{|c|}{ Tabel Rasio } \\
\hline No & Ratio & asusid & apple & dell & acerid & hpindonesia & lenovoid \\
\hline & $\begin{array}{c}\text { VIDEO } \\
\text { COMMENTS TO } \\
\text { FOLLOWERS } \\
\text { RATIO }\end{array}$ & 0,00006426 & 0,00007204 & 0,00009569 & 0,00017128 & 0,00035045 & 0,00067950 \\
\hline
\end{tabular}

Sumber : Pengolah Data Microsoft Excel

Video Comments to Followers Ratio memiliki karakteristik yang tinggi, dimana hal ini berarti semakin tinggi nilai yang dihasilkan atau di dapat maka semakin baik kredibilitas dari performa akun Instagram tersebut. Untuk memberikan peringkat pada masing-masing Merk Laptop tersebut, peneliti memberikan angka 6 kepada merk laptop yang mendapatkan nilai tertinggi dan angka 1 untuk merk laptop yang mendapatkan nilai terendah. Berikut ini merupakan table urutan nilai yang didapat atau dihasilkan oleh masing-masing merk laptop yang banyak digunakan.

Tabel 9. Nilai Rasio Akun Instagram 6 Daftar Merk Laptop Terbaik Paling Banyak Digunakan

\begin{tabular}{|c|c|c|c|c|c|}
\hline \multicolumn{7}{|c|}{ Tabel Nilai Rasio } \\
\hline asusid & apple & dell & acerid & hpindonesia & lenovoid \\
\hline 1 & 2 & 3 & 4 & 5 & 6 \\
\hline
\end{tabular}


Dilihat dari Tabel Nilai Rasio Akun Instagram 6 Daftar Merk Laptop Terbaik Paling Banyak Digunakan dapat disimpulkan bahwa Lenovo Indonesia dengan nama akun Instagramnya lenovoid mendapatkan nilai tertinggi untuk rasio Video Comments to Followers. Sedangkan akun Instagram Asus Indonesia dengan nama akun asusid mendapatkan nilai terendah untuk rasio ini. Jadi, pada penelitian ini Lenovo Indonesia (lenovoid) memiliki kredibilitas performa yang lebih baik dibandingan dengan merk laptop yang lainnya.

\section{KESIMPULAN}

Tujuan dari penelitian ini adalah untuk mengetahui kredibilitas performa dari akun Instagram 6 Daftar Merk Laptop Terbaik Paling Banyak Digunakan dengan menggunakan Video Comments to Followers Ratio. Akun Instagram dari 6 Daftar Merk Laptop Terbaik Paling Banyak Digunakan tersebut diantaranya adalah : asusid, apple, dell, acerid, hpindonesia, dan lenovoid. Dari keenam merk laptop tersebut dapat disimpulkan bahwa :

1. Peringkat pertama diraih oleh merk laptop Lenovo Indonesia dengan nama akun Instagram lenovoid mendapatkan perolehan nilai tertinggi yaitu : 0,00067950

2. Peringkat kedua diraih oleh merk laptop HP Indonesia dengan nama akun Instagram hpindonesia mendapatkan perolehan nilai : 0,00035045

3. Peringkat ketiga diraih oleh merk laptop Acer Indonesia dengan nama akun Instagram acerid mendapatkan perolehan nilai : 0,00017128

4. Peringkat keempat diraih oleh merk laptop Dell dengan nama akun Instagram dell mendapatkan perolehan nilai : 0,00009569

5. Peringkat ketiga diraih oleh merk laptop Apple dengan nama akun Instagram apple mendapatkan perolehan nilai : 0,00007204

6. Peringkat ketiga diraih oleh merk laptop Asus Indonesia dengan nama akun Instagram asusid mendapatkan perolehan nilai : 0,00006426 


\section{DAFTAR PUSTAKA}

Feroza, C. S., \& Misnawati, D. (2020). Penggunaan media sosial instagram pada pkun @ yhoophii_official sebagai media komunikasi dengan pelanggan. Jurnal Inovasi, 14(1), $32-41$.

Hendika Permana, I. P. (2021). Analisis Rasio Pada Akun Instagram Untuk Penelitian Kualitatif Menggunakan Metode Ekploratif. Jurnal Ilmiah Media Sisfo, 15(1), 40. https://doi.org/10.33998/mediasisfo.2021.15.1.970

Mahendra, B. (2017). Eksistensi Sosial Remaja Dalam Instagram (Sebuah Perspektif Komunikasi). Jurnal Visi Komunikasi, 16(1), 151-160.

Maulhayat, F., Kesuma, A. I., \& Amiruddin, H. (2018). Peran Instagram di Kalangan Mahasiswa Angkatan 2015 Fakultas Ilmu Sosial Universitas Negeri Makassar. Eprints.Unm, 1-18.

http://eprints.unm.ac.id/9871/\%0Ahttps://id.wikipedia.org/wiki/InstagramSeiri

Mudjiyanto, B. (2018). Tipe Penelitian Eksploratif Komunikasi. Jurnal Studi Komunikasi Dan Media, 22(1), 65. https://doi.org/10.31445/jskm.2018.220105

Nainggolan, V., Randonuwu, S. A., \& Waleleng, G. J. (2018). Peranan Media Sosial Instagram dalam Interaksi Sosial Antar Mahasiswa Fakultas Ilmu Sosial dan Politik Unsrat Manado. Jurnal Acta Diurna, 7(4), 1-15.

https://ejournal.unsrat.ac.id/index.php/actadiurnakomunikasi/article/view/22022

Purwanto, N. (2019). Variabel Dalam Penelitian Pendidikan. Jurnal Teknodik, 6115, 196215. https://doi.org/10.32550/teknodik.v0i0.554

Sukma Convert. (2021). Apa Saja Daftar Merk Laptop Terbaik yang Paling Laris. 14 April. https://www.sukmaconvert.com/merk-laptop-terbaik/ 